\title{
YIELD RESPONSE AND NITROGEN USE EFFICIENCY OF BORO RICE VARIETIES AS AFFECTED BY DIFFERENT METHODS OF USG AND PRILLED UREA APPLICATION
}

\author{
M.K.A. Bhuiyan ${ }^{1 *}$, L. Nahar ${ }^{1}$, M.M. Mahbub ${ }^{1}$, R.Shultana ${ }^{1}$, M.A.J. Mridha ${ }^{1}$, \\ M.A. Rahman ${ }^{2}$ and M. Kamruzzaman ${ }^{2}$ \\ ${ }^{1}$ Agronomy Division, ${ }^{2}$ FMPHT Division, Bangladesh Rice Research Institute, Gazipur, Bangladesh \\ Corresponding Author: bhuiyan072003@yahoo.com
}

Key words: USG and Prilled urea applicator, Nitrogen use efficiencies, BRRI dhan28 and BRRI dhan29

\begin{abstract}
An experiment was conducted at the Bangladesh Rice Research Institute (BRRI), Gazipur during Boro season of 2013-14 and 2014-15 to find out the nitrogen use efficiency and yield of boro rice var. BRRI dhan28 and BRRI dhan29 under four $\mathrm{N}$ management practices such as application of prilled urea using prilled urea applicator, application of USG (2.7gm) using USG applicator, broadcasting of prilled urea following three splits and a control (without urea). The experimental design was RCBD replicated thrice. BRRI dhan29 with urea broadcasted plots produced higher grain yield $\left(7.38 \mathrm{tha}^{-1}\right)$ followed by BRRI dhan29 with USG application $\left(6.65 \mathrm{t} \mathrm{ha}^{-1}\right)$. Hand broadcasting with urea fertilizer showed 15.38 .5 and $2.5,9.89 \%$ higher grain yield than machine application of prilled urea and USG in BRRI dhan28 and BRRI dhan29, respectively. Grain yield showed a significant quadratic response to $\mathrm{N}$ fertilization and significant linear response with total dry matter production in both the varieties. Higher total $\mathrm{N}$ was uptake from urea broadcasted plots in BRRI dhan29 followed by urea broadcasted from BRRI dhan28. BRRI dhan29 with Prilled urea applicator and BRRI dhan29 with USG treatment uptake intermediate nitrogen. N uptake in grain and total $\mathrm{N}$ uptake had a significant linear and quadratic response to $\mathrm{N}$ treatment in BRRI dhan28 and BRRI dhan29. Nitrogen use efficiency was higher in BRRI dhan29 compared to BRRI dhan28. Economic analysis showed that rice var. BRRI dhan28 and BRRI dhan29 with urea broadcast had the highest gross return of Tk.145145.00 and Tk. $158310.00 \mathrm{ha}^{-1}$, respectively. However, the maximum cost (Tk. 151131) was involved for BRRI dhan29 with urea broadcasting, while the minimum with no urea fertilizer application for both the varieties. The highest marginal rate of return (MRR) (Tk.1146) was recorded from BRRI dhan28 with USG application using BRRI applicator.
\end{abstract}

\section{Introduction}

Nitrogen loss processes are due to ammonia volatilization, denitrification, runoff, seepage and leaching which can be improve nitrogen use efficiency for rice production. Deep placement of nitrogen fertilizer into the anaerobic soil zone is a recognized effective method to reduce its volatilization loss from rice field. Urea in the form of USG (Urea Super Granule) has been proved to be superior to granular urea in all aspects. Instead of normal does of 247 $\mathrm{kg}$ granular urea, only $160 \mathrm{~kg} \mathrm{ha}^{-1}$ of USG was required (35\% less) even to increase $20 \%$ rice yield (Hoque et. al., 2013). Depending on agro-climate and nitrogen use, deep-placed USG can save urea fertilizer up to $65 \%$ with a $33 \%$ increase in grain yields, and up to $50 \%$ with 15 to $20 \%$ yield increase over the same amount of split-applied nitrogen as prilled urea 
Bhuiyan et al.

(Fatema-Tuz-Zohra et al. 2013). It is reported that USG placement at 6-10 cm depth in wet land rice field can save $30 \%$ nitrogen compared to broadcasted prilled urea. Hand placement of USG of $1.8 \mathrm{~g}$ to $2.7 \mathrm{~g}$ sizes into flood soil resulted in less loss of nitrogen, higher nitrogen recovery and higher yield than conventional nitrogen application method (Hoque et al., 2013). USG is presently applied manually. It is placed at a depth of 8 to $10 \mathrm{~cm}$ of the soil at the center of 4 consecutive hills of 2 adjacent rows, which is labor intensive, cumbersome and very slow method, i.e. 0.07 to 0.12 ha/workday. Unfortunately, farmers have not been able to be benefited from these findings, primarily because they have no suitable fertilizer placement equipment. Recently BRRI has developed a prilled urea applicator, by which the fertilizer can be placed in a reduced zone of soil and saved about 30-35\% without sacrificing grain yield. BRRI prilled urea applicator was designed and developed by considering plant spacing of $20 \mathrm{~cm} \times 20 \mathrm{~cm}$. It is also handy and work efficient. This study was therefore designed to analyze nitrogen use efficiency and yield performance of two popular boro rice varieties, BRRI dhan28 and BRRI dhan29, as affected by different sources of nitrogen and its application methods.

\section{Materials and Methods}

\section{Experimental site and soil}

The present study was conducted at the experimental field of Bangladesh Rice Research Institute (BRRI), Gazipur situated at $23^{\circ} 59^{\prime} 33^{\prime \prime} \mathrm{N}$ and $90^{\circ} 24^{\prime} 19^{\prime \prime} \mathrm{E}$ at an elevation of $8.4 \mathrm{~m}$ from the mean sea level, and is characterized by sub-tropical climate. The soil of the field was clay loam of shallow brown terrace under Madhupur tract (AEZ 28), the experimental field classified as a Chhiata clay loam, hyperthermic Vertic Endoaquept. The chemical properties of the soil are presented in Table 1. The soil of the experimental plot was neutral acidic in nature $\left(\mathrm{P}^{\mathrm{H}}=6.3\right)$ and poor in fertility status.

The experiment was conducted at BRRI farm, Gazipur during Boro season of 2013-14 and 2014-15 to find out NUEs and response of BRRI dhan28 and BRRI dhan29 under four N management practices such as i) Urea application by Prilled urea applicator ii) USG (2.7 g) application by USG applicator, iii) hand broadcasting of prilled urea with three splits and iv) control (without urea). The experiment was conducted in factorial RCBD design with three replications. Unit plot size was $6 \mathrm{~m} \times 4.8 \mathrm{~m}$ transplanted with $20 \mathrm{~cm} \times 20 \mathrm{~cm}$ spacing. BRRI recommended managements were followed for raising seedlings and for other intercultural operations. Fertilizer TSP, $\mathrm{M}_{\mathrm{O}} \mathrm{P}$, Gypsum and zinc sulphate were added as basal. Prilled urea and USG $(2.7 \mathrm{~g})$ by prilled urea applicator and USG applicator were applied 3 days after planting. Prilled urea top dress were completed in three equal splits, at 15, 35 and 55 DAT. Thirty- eight -days old seedlings were transplanting on $16^{\text {th }}$ and $18^{\text {th }}$ August in 2013-14 and 2014-15, respectively. Grain and straw samples were collected from each plot, oven dried at $65^{\circ} \mathrm{C}$ and grains was measured by the standard Micro-Kjeldahl procedure (Bremner and Mulvaney, 1982). $\mathrm{N}$ uptake in grain and straw were calculated by following formulae.

Nitrogen uptake by grain $\left(\mathrm{kg} \mathrm{ha}^{-1}\right)=\frac{\% \mathrm{~N} \text { in grain } \times \text { Grain yield }\left(\mathrm{kg} \mathrm{ha}^{-1}\right)}{100}$

Nitrogen uptakeby straw $\left(\mathrm{kgha}^{-1}\right)=\frac{\% \mathrm{~N} \text { in straw } \times \text { straw yieb }\left(\mathrm{kgha}^{-1}\right)}{100}$ 
Yield Response and Nitrogen Use Efficiency of Boro Rice Varieties as Affected by Different Methods

Agronomic efficiency, physiological efficiency, agro-physiological efficiency, apparent recovery efficiency, and utilization efficiency are calculated by using the formulas described by Fageria et al. (1997); Fageria and Baligar (2001). Data on yield and yield components were recorded at maturity. Economic analysis was done to determine the efficiency of different treatments following the procedure of Marginal Rate of Return (MRR) by CIMMYT (1988).

In a combined analysis of data, the interaction of year, $\mathrm{N}$ levels, and varieties was nonsignificant so, pooled analyses was done and means were compared by LSD test.

\section{Results and Discussion}

\section{Yield and yield character and total dry matter}

Nitrogen and varieties showed insignificant effect on plant height, the individual effect of $\mathrm{N}$ on plant height was significant $(p<0.01)$. In BRRI dhan28, USG treated plot produced the highest plant height, whereas urea broadcasting produced in BRRI dhan29. BRRI dhan29 produced higher panicle $/ \mathrm{m}^{2}$ compared to BRRI dhan28where maximum panicle was produced by urea hand broadcasting treatment (358) followed by $\mathrm{N}$ application by prilled urea applicator (320). In BRRI dhan28 the maximum panicle was produced by urea hand broadcasting (298) followed by USG (288). Thousand grain weight showed insignificant effect on nitrogen and variety interaction. BRRI dhan29 produced the highest grain yield (7.38t ha $\mathrm{h}^{-1}$ ) in urea hand broadcasting plots followed by N application of USG applicator. In BRRI dhan28, similar results were observed. The lowest grain yield was observed from control plots in both varieties. Figure 1 (A) showed grain yield showed a significant quadratic response to $\mathrm{N}$ fertilization in both the varieties. Regression analysis showed highest grain yield of BRRI dhan28 and BRRI dhan29 was obtained with urea hand broadcasting treatment (124 $\mathrm{kg} \mathrm{N} \mathrm{ha}^{-1}$ ). Singh et al. (1998) reported that maximum average grain yield 7.7 $\mathrm{t} \mathrm{ha}{ }^{-1}$ of lowland rice genotypes was obtained at 150 to $200 \mathrm{~kg} \mathrm{~N}^{-1}$. The relationship of grain yield with total dry matter yield showed highly significant and linear (figure $1 \mathrm{~B}$ ). Fageria and Baligar (2001) reported that grain yield in lowland rice increased significantly and quadratically with increasing dry matter weight.

\section{Grain harvest index (GHI) and N harvest index (NHI)}

Individual effect of $\mathrm{N}$ and varieties on $\mathrm{GHI}$ was significant but their interaction was not significant. Grain harvest index varied from 0.40 to 0.52 with an average value of 0.48 in BRRI dhan28 and 0.42 to 0.54 with an average value of 0.50 in BRRI dhan29 (Table 4). Figure 2 showed the Kiniry et al. (2001) reported that the GHI varied greatly among cultivars, locations, seasons, and ecosystems, ranging from 0.35 to 0.62 , indicating the importance of this variable for yield stimulation.

Nitrogen harvest index (NHI) showed insignificant in $\mathrm{N}$ and varieties but significant in interaction (Table 5). The NHI values varied from 0.65 to 0.67 , with an average value of 0.67 for BRRI dhan28 and from 0.64 to 0.88 , with an average value of 0.66 for BRRI dhan29. Fageria and Barbosa Filho (2001) reported that NHI values varied from 0.44 to 0.66 in lowland rice depending on genotypes.

\section{Nitrogen concentration (\%) and uptake in grain and straw}


Bhuiyan et al.

The nitrogen and variety interactions in relation to grain $\mathrm{N}$ concentration (\%) were not significant in BRRI dhan28 and BRRI dhan29 (Table 5). But higher grain $\mathrm{N}$ was absorbed in BRRI dhan29 compared to BRRI dhan28. In BRRI dhan29 urea hand broadcasted plot observed higher grain N\% followed by USG treated plots. But in BRRI dhan28 USG treated plots accumulated higher grain N\% followed by urea hand broadcasted plots. In both the varieties urea hand broadcasted plots accumulated highest straw $\mathrm{N}$. BRRI dhan29 accumulated average highest total $\mathrm{N}(1.58 \%)$ compared to $\mathrm{N}$ accumulated from $\mathrm{BRRI}$ dhan29 (1.54\%) while control plot produced the lowest N\%.

$\mathrm{N}$ uptake in grain was highest in urea broadcasted plots $\left(79.72 \mathrm{~kg} \mathrm{ha}^{-1}\right)$ followed by prilled urea applicator plots in BRRI dhan29 (Table 5). But in BRRI dhan28 highest grain $\mathrm{N}$ was uptake from USG treated plots $\left(71.63 \mathrm{~kg} \mathrm{ha}^{-1}\right)$ followed by urea hand broadcasted plots. In $\mathrm{BRRI}$ dhan29 maximum straw $\mathrm{N}$ was uptake from urea hand broadcasted plots followed by plots from prilled urea applicator plots. In BRRI dhan28 highest straw $\mathrm{N}$ was uptake from urea hand broadcasted plots followed by USG plots. Highest total N was uptake from urea broadcasted plots in BRRI dhan29 followed by urea broadcasted plots from BRRI dhan28.

$\mathrm{N}$ uptake in grain and total $\mathrm{N}$ uptake had a significant linear and quadratic response to $\mathrm{N}$ treatment from different sources in BRRI dhan28 and BRRI dhan29 (Figure 3A, 3B). N uptake in grain also had a quadric relationship in BRRI dhan28 and in BRRI dhan29 (Figure $3 \mathrm{~B})$. In both the varieties grain yield was significantly and linearly related with $\mathrm{N}$ uptake in grain $\left(R^{2}=0.96\right.$ and 0.99 for $B R R I$ dhan29 and BRRI dhan28) and with total $N$ uptake $\left(R^{2}=\right.$ 0.990 and 0.999 for BRRI dhan29 and BRRI dhna28), respectively) (Figure 3A and B), indicating that, in most cases, higher grain yield would be due to higher $\mathrm{N}$ uptake. Likewise, an increase of the total $\mathrm{N}$ uptake implied an increase on the total dry matter production in both the varieties (Figure 3C). Almost 94.4 and $99.1 \%$ of the variation in total dry matter production was explained by $\mathrm{N}$ uptake in BRRI dhan29 and BRRI dhan28, respectively. Pamela et al. (2009) reported $\mathrm{N}$ uptake in grain and total $\mathrm{N}$ uptake had a significant quadratic response to $\mathrm{N}$ fertilization but total $\mathrm{N}$ uptake increased significantly and linearly with $\mathrm{N}$ levels.

\section{Nitrogen Use Efficiencies (NUEs)}

Effect of $\mathrm{N}$ treatment on NUEs was significant in AE, PE, UE and PFP. The highest AE (49) was observed in BRRI dhan28 with N application from USG by USG applicator. The lowest AE (31) was found from BRRI dhan28 with $\mathrm{N}$ application from urea broadcasting. The highest PE (128) was observed in BRRI dhan29 with $\mathrm{N}$ application from USG by USG applicator while lowers with $\mathrm{N}$ application by broadcasting with three splits. The highest APE (84) was observed in BRRI dhan29 with N application from USG by USG applicator. The lowest APE was found from BRRI dhan29 and BRRI dhan28 with $\mathrm{N}$ application by broadcasting with three splits. Singh et al. (1998) reported an agrophysiological efficiency of about $64 \mathrm{~kg}$ grain per $\mathrm{kg}$ of $\mathrm{N}$ uptake and agronomic efficiency of $37 \mathrm{~kg}$ grain per $\mathrm{kg}$ of $\mathrm{N}$ applied in 20 lowland rice genotypes. USG application by USG applicator and BRRI dhan28 produced the value (83) where as BRRI dhan28 with prilled urea applicator and USG with BRRI dhan29 found the lower recovery efficiency. The highest UE (108) was produced from BRRI dhan29 x USG application by USG applicator and the lowest from BRRI dhan29 urea broadcasted following three splits. PFP was highest in BRRI dhan29 x USG (89) application by USG applicator followed by BRRI dhan28 x USG (84) application by USG applicator treatment. The lowest PFP was observed from urea broadcasting in three splits in both BRRI dhan28 and BRRI dhan29. On average nitrogen use efficiencies was higher in BRRI dhan29 compared to BRRI dhan28. 
Yield Response and Nitrogen Use Efficiency of Boro Rice Varieties as Affected by Different Methods

\section{Economic analysis}

Economics analysis was shown in Tables 6, 7 and 8.

Table 6 indicated that the urea broadcasting with three splits with BRRI dhan29 showed the maximum gross return followed by urea broadcasting in BRRI dhan28. Cost dominance analyses (Table 7) showed that cost was highest (Tk. 150831) for the treatment prilled urea broadcasting with BRRI dhan29 and lowest for control plots of both the varieties.. From Table 8, it was observed that the treatment BRRI dhan28x Prilled urea broadcasting and BRRI dhan28xPrilled urea applicator were found cost dominated, where cost is more but gross margin is less than that of other treatments.

The treatment BRRI dhan28 following USG application by USG applicator showed the highest MRR (Tk.1146) and was more profitable than other $N$ treatments as a result interaction of BRRI dhan28 $\times$ USG application by USG applicator was more profitable than other $\mathrm{N}$ management treatments.

\section{Conclusion}

The findings of the study indicated that even though the highest grain yield was recorded from PU application by three splits, the NUE was higher in BRRI dhan $28 \times$ USG application plots. USG application by applicator in both BRRI dhan28 and BRRI dhan29 saved $40 \%$ nitrogen with intermediate grain yield. Economic analysis by MRR (Marginal rate of return) indicated that BRRI dhan28 $\times$ USG application by USG applicator had the highest MMR (1144.86) over other treatments. However, some practical limitations related to accurate calibration and mechanical sophistication need to be resolved to improve further the efficiency of the applicator.

Table 1. Initial soil chemical properties at $0-15 \mathrm{~cm}$ soil depth in the experimental plot

\begin{tabular}{|c|c|c|}
\hline Soil properties & Value & SE $( \pm)$ \\
\hline Soil pH & 6.3 & 0.19 \\
\hline Organic matter & $2.05 \%$ & 0.27 \\
\hline Total $\mathrm{N}$ content & $0.09 \%$ & 0.005 \\
\hline Available phosphorus (P) & $\begin{array}{l}11.14 \mathrm{mg} \mathrm{kg}^{-1} \\
\left(0.5 \mathrm{M} \mathrm{NaHCO}_{3} \text { extracted }\right)\end{array}$ & 0.094 \\
\hline Exchangeable potassium (K) & $\begin{array}{l}0.18 \mathrm{meq} / 100 \mathrm{~g} \text { soil } \\
\text { (Neutral } 1.0 \mathrm{~N} \mathrm{NH}_{4} \mathrm{OAc} \text { extracted) }\end{array}$ & 0.018 \\
\hline Available sulfur (S) & $22 \mathrm{mg} \mathrm{kg}^{-1}\left[\mathrm{Ca}\left(\mathrm{H}_{2} \mathrm{PO}_{4}\right)_{2}\right.$ extracted $]$ & 1.76 \\
\hline Available zinc (Zn) & $2.85 \mathrm{mg} \mathrm{kg}^{-1}(0.01 \mathrm{~N} \mathrm{HCl}$ extracted $)$ & 0.08 \\
\hline
\end{tabular}

Table 2. Effect of varieties and nitrogen management on plant height, yield and yield contributing characters during Boro season. BRRI, Gazipur

\begin{tabular}{lcccccc}
\hline $\begin{array}{l}\text { Nitrogen } \\
\text { management }\end{array}$ & $\begin{array}{c}\mathrm{N} \text { rate } \\
\left(\mathrm{Kg} \mathrm{ha}^{-1}\right.\end{array}$ & $\begin{array}{c}\text { Plant } \\
\text { height }\end{array}$ & $\begin{array}{c}\text { Panicle } \\
\mathrm{m}^{-2}\end{array}$ & $\begin{array}{c}\text { Grains } \\
\text { panicle }^{-1}\end{array}$ & $\begin{array}{c}1000- \\
\text { grain }\end{array}$ & $\begin{array}{c}\text { Grain } \\
\text { yield }\end{array}$ \\
\hline
\end{tabular}


Bhuiyan et al.

\begin{tabular}{|c|c|c|c|c|c|c|}
\hline$(\mathrm{N})$ & & $(\mathrm{cm})$ & & & weight & $\left(\mathrm{t} \mathrm{ha}^{-1}\right)$ \\
\hline \multicolumn{7}{|c|}{ BRRI dhan28 } \\
\hline Control & 0 & 87.54 & 207 & 75 & 20.61 & 2.59 \\
\hline PUA & 87 & 98.67 & 248 & 85 & 21.61 & 5.47 \\
\hline USG & 75 & 102.12 & 288 & 87 & 23.24 & 6.30 \\
\hline PUB & 124 & 99.75 & 298 & 91 & 22.09 & 6.46 \\
\hline Avg. & & 97.02 & 260 & 84 & 21.88 & 5.21 \\
\hline \multicolumn{7}{|c|}{ BRRI dhan29 } \\
\hline Control & 0 & 92.70 & 205 & 76 & 21.27 & 3.11 \\
\hline PUA & 87 & 102.75 & 320 & 92 & 22.07 & 6.75 \\
\hline USG & 75 & 99.06 & 317 & 89 & 21.79 & 6.65 \\
\hline PUB & 124 & 102.96 & 358 & 98 & 22.66 & 7.38 \\
\hline \multicolumn{2}{|l|}{ Avg. } & 99.36 & 300 & 89 & 21.94 & 5.97 \\
\hline $\operatorname{LSD}_{(0.05)}$ for $\mathrm{N}$ & & 5.45 & 10.61 & 4.32 & ns & 0.29 \\
\hline $\operatorname{LSD}_{(0.05)}$ for $\mathrm{V}$ & & ns & 7.50 & 3.05 & ns & 0.21 \\
\hline $\operatorname{LSD}_{(0.05)}$ for $\mathrm{N} \times \mathrm{V}$ & & ns & 15.00 & ns & ns & 0.41 \\
\hline CV (\%) & & 4.5 & 3.1 & 4.0 & 4.6 & 4.2 \\
\hline
\end{tabular}

Control= No Urea, $\mathrm{PUA}=$ Prilled urea Applicator, $\mathrm{USG}=$ Urea super granule $\mathrm{PUB}=$ Urea broadcasting

Table 3. Grain harvest index $(\mathrm{GHI})$ and $\mathrm{N}$ harvest index $(\mathrm{NHI})$ of $\mathrm{BRRI}$ dhan28 and BRRI dhan29 as influenced by $\mathrm{N}$ fertilization from different source and method of application

\begin{tabular}{|c|c|c|c|c|c|}
\hline \multirow[t]{2}{*}{ N source } & \multirow{2}{*}{$\begin{array}{l}\text { N rate } \\
\mathrm{Kg} \mathrm{ha}^{-1}\end{array}$} & \multicolumn{2}{|c|}{ Grain harvest index } & \multicolumn{2}{|c|}{$\mathrm{N}$ harvest index } \\
\hline & & $\begin{array}{c}\text { BRRI } \\
\text { dhan28 }\end{array}$ & BRRI dhan29 & $\begin{array}{c}\text { BRRI } \\
\text { dhan28 }\end{array}$ & BRRI dhan29 \\
\hline Control & 0 & 0.40 & 0.42 & 0.65 & 0.68 \\
\hline PUA & 87 & 0.51 & 0.52 & 0.67 & 0.65 \\
\hline USG & 75 & 0.50 & 0.54 & 0.69 & 0.65 \\
\hline PUB & 124 & 0.52 & 0.53 & 0.66 & 0.64 \\
\hline Average & & 0.48 & 0.50 & 0.67 & 0.66 \\
\hline \multicolumn{2}{|c|}{$\operatorname{LSD}_{(0.05)}$ for $\mathrm{N}$} & \multicolumn{2}{|c|}{0.22} & \multicolumn{2}{|r|}{ Ns } \\
\hline \multicolumn{2}{|c|}{$\operatorname{LSD}_{(0.05)}$ for $\mathrm{V}$} & \multicolumn{2}{|c|}{0.16} & \multicolumn{2}{|c|}{ Ns } \\
\hline \multicolumn{2}{|c|}{$\operatorname{LSD}_{(0.05)}$ for $\mathrm{N} \times \mathrm{V}$} & \multicolumn{2}{|c|}{ Ns } & \multicolumn{2}{|c|}{0.35} \\
\hline \multicolumn{2}{|c|}{ CV $(\%)$} & \multicolumn{2}{|c|}{3.7} & \multicolumn{2}{|c|}{3.0} \\
\hline
\end{tabular}

Table 4. Effect of varieties and nitrogen management on $N(\%)$ and uptake during Boro season at BRRI, Gazipur

\begin{tabular}{|c|c|c|c|c|c|c|c|}
\hline \multirow[t]{2}{*}{$\mathrm{N}$ management $(\mathrm{N})$} & \multirow{2}{*}{$\begin{array}{c}\mathrm{N} \\
\text { rate }\end{array}$} & \multicolumn{3}{|c|}{ Nitrogen (\%) } & \multicolumn{3}{|c|}{ Nitrogen uptake $\left(\mathrm{kg} \mathrm{ha}^{-1}\right)$} \\
\hline & & Grain & Straw & Total & Grain & Straw & Total \\
\hline \multicolumn{8}{|c|}{ BRRI dhan28 } \\
\hline Control & 0 & 0.84 & 0.46 & 1.31 & 22.14 & 18.02 & 40.16 \\
\hline
\end{tabular}


Yield Response and Nitrogen Use Efficiency of Boro Rice Varieties as Affected by Different Methods

\begin{tabular}{|c|c|c|c|c|c|c|c|}
\hline PUA & 87 & 1.06 & 0.51 & 1.58 & 60.81 & 26.82 & 87.63 \\
\hline USG & 75 & 1.12 & 0.50 & 1.63 & 71.84 & 30.41 & 102.26 \\
\hline PUB & 124 & 1.08 & 0.55 & 1.64 & 71.63 & 35.19 & 106.83 \\
\hline Avg. & & 1.02 & 0.51 & 1.54 & 56.60 & 27.61 & 84.22 \\
\hline \multicolumn{8}{|c|}{ BRRI dhan29 } \\
\hline Control & 0 & 0.91 & 0.42 & 1.33 & 29.85 & 18.02 & 47.87 \\
\hline PUA & 87 & 1.07 & 0.58 & 1.65 & 67.73 & 35.52 & 103.24 \\
\hline USG & 75 & 1.03 & 0.54 & 1.57 & 61.56 & 28.11 & 89.67 \\
\hline PUB & 124 & 1.13 & 0.64 & 1.77 & 79.72 & 42.39 & 122.09 \\
\hline Avg. & & 1.03 & 0.54 & 1.58 & 59.71 & 31.01 & 90.72 \\
\hline $\operatorname{LSD}_{(0.05)}$ for $\mathrm{N}$ & & ns & 0.43 & 0.10 & 8.37 & 4.35 & 9.74 \\
\hline $\operatorname{LSD}_{(0.05)}$ for $\mathrm{V}$ & & ns & 0.30 & ns & ns & 3.07 & ns \\
\hline $\operatorname{LSD}_{(0.05)}$ for $\mathrm{N} \times \mathrm{V}$ & & ns & 0.61 & ns & ns & 6.15 & 13.77 \\
\hline $\mathrm{CV}(\%)$ & & 6.9 & 6.6 & 5.2 & 11.60 & 12.0 & 9.0 \\
\hline
\end{tabular}

Table 5. $\mathrm{N}$ use efficiencies of different $\mathrm{N}$ sources and method of application in variety and nitrogen interaction during Boro 2014 at BRRI, Gazipur

\begin{tabular}{|c|c|c|c|c|c|c|c|}
\hline \multirow{2}{*}{$\begin{array}{c}\mathrm{N} \\
\text { manage } \\
\text { ment }\end{array}$} & \multirow[t]{2}{*}{$\mathrm{N}$ rate } & \multicolumn{6}{|c|}{ Nitrogen use efficiencies } \\
\hline & & $\begin{array}{c}\mathrm{AE} \\
\left(\mathrm{kg} \mathrm{ha}^{-1}\right)\end{array}$ & $\begin{array}{c}\mathrm{PE} \\
\left(\mathrm{kg} \mathrm{ha}^{-1}\right)\end{array}$ & $\begin{array}{c}\text { APE } \\
\left(\mathrm{kg} \mathrm{ha}^{-1}\right)\end{array}$ & $\begin{array}{c}\text { ARE } \\
(\%)\end{array}$ & $\begin{array}{c}\text { UE } \\
\left(\mathrm{kg}_{1} \text { ha }\right. \\
\left.{ }^{\prime}\right)\end{array}$ & $\begin{array}{c}\text { PFP } \\
\left(\mathrm{kg} \mathrm{ha}^{-1}\right)\end{array}$ \\
\hline \multicolumn{8}{|c|}{ BRRI dhan28 } \\
\hline PUA & 87 & 33 & 102 & 67 & 55 & 72 & 63 \\
\hline USG & 75 & 49 & 106 & 60 & 83 & 63 & 84 \\
\hline PUB & 124 & 31 & 95 & 58 & 54 & 56 & 52 \\
\hline Avg. & & 38 & 101 & 62 & 64 & 64 & 66 \\
\hline \multicolumn{8}{|c|}{ BRRI dhan29 } \\
\hline PUA & 75 & 42 & 110 & 65 & 64 & 71 & 78 \\
\hline USG & 124 & 47 & 128 & 84 & 56 & 108 & 89 \\
\hline PUB & 0 & 34 & 91 & 58 & 60 & 53 & 60 \\
\hline Avg. & & 41 & 110 & 69 & 60 & 77 & 76 \\
\hline $\operatorname{LSD}_{(0.05)}$ & & 5.10 & 15.72 & ns & ns & 24.69 & 3.70 \\
\hline $\operatorname{LSD}_{(0.05)}$ & & Ns & Ns & Ns & Ns & Ns & 2.02 \\
\hline $\operatorname{LSD}_{(0.05)}$ & $\mathrm{N} \times \mathrm{V}$ & Ns & Ns & Ns & 19.56 & Ns & 5.24 \\
\hline CV (\%) & & 10.0 & 11.6 & 18.3 & 17.4 & 27.2 & 2.8 \\
\hline
\end{tabular}

NS= Not significant at the 0.05 probability level.

$\mathrm{AE}=$ Agronomic Efficiency, $\mathrm{PE}=$ Physiological Efficiency, APE= Agro-physiological Efficiency, $\mathrm{ARE}=$ Apparent Recovery Efficiency, UE= Utilization Efficiency, PFP= Partial Factor Productivity Table 6. Cost return analysis of variety and management

\begin{tabular}{l|c|c|c}
\hline $\begin{array}{l}\text { Variety } \times \text { N management } \\
\text { treatment }\end{array}$ & $\begin{array}{c}\text { Variable cost } \\
\left(\text { Tk. ha }^{-1}\right)\end{array}$ & $\begin{array}{c}\text { Gross return } \\
\left(\text { Tk. ha }^{-1}\right)\end{array}$ & $\begin{array}{c}\text { Gross margin } \\
\left(\text { Tk. ha }^{-1}\right)\end{array}$ \\
\hline BRRI dhan28×N0 & 0 & 65956 & 65956 \\
BRRI dhan28×PUA & 4990 & 126676 & 121686 \\
\hline
\end{tabular}


Bhuiyan et al.

\begin{tabular}{lccc}
\hline BRRI dhan28×USG & 4782 & 140860 & 136078 \\
BRRI dhan28×PUB & 7438 & 145145 & 137707 \\
BRRI dhan29×NO & 0 & 81270 & 81270 \\
BRRI dhan29×PUA & 4823 & 141195 & 136372 \\
BRRI dhan29×USG & 4900 & 141696 & 136796 \\
BRRI dhan29×PUB & 7479 & 158310 & 150831 \\
\hline
\end{tabular}

Table 7. Cost dominated treatment (Variety $\times \mathrm{N}$ fertilizer)

\begin{tabular}{|c|c|c|c|}
\hline $\begin{array}{l}\text { Gross margin } \\
\left(\text { Tk. ha }{ }^{-1}\right)\end{array}$ & Treatments & $\begin{array}{c}\text { Variable cost } \\
\left(\text { Tk. ha }{ }^{-1}\right)\end{array}$ & $\begin{array}{c}\text { Cost dominated } \\
\text { treatment }\end{array}$ \\
\hline 150831 & BRRI dhan29× PUB & 7479 & \\
\hline 137707 & BRRI dhan28× PUB & 7438 & * \\
\hline 136796 & BRRI dhan29×USG & 4900 & \\
\hline 136372 & BRRI dhan29×PUA & 4823 & \\
\hline 136078 & BRRI dhan28×USG & 4782 & \\
\hline 121686 & BRRI dhan28×PUA & 4990 & * \\
\hline 81270 & BRRI dhan29×N0 & 0 & \\
\hline 65956 & BRRI dhan28×N0 & 0 & \\
\hline
\end{tabular}

Table 8. Marginal rate of return of the applied (Variety $\times \mathrm{N}$ fertilizer)

\begin{tabular}{|c|c|c|c|c|c|}
\hline $\begin{array}{c}\text { Gross } \\
\text { margin } \\
\left(\text { Tk. ha }^{-1}\right)\end{array}$ & Treatments & $\begin{array}{c}\text { Variable } \\
\text { cost } \\
\left(\text { Tk. ha }^{-1}\right)\end{array}$ & $\begin{array}{c}\text { Marginal } \\
\text { variable cost } \\
\left(\text { Tk ha }^{-1}\right)\end{array}$ & $\begin{array}{l}\text { Marginal } \\
\text { gross } \\
\text { margin } \\
\left(\mathrm{Tk}^{-1} \mathrm{ha}^{-1}\right)\end{array}$ & $\begin{array}{l}\text { Marginal } \\
\text { rate of } \\
\text { return }\end{array}$ \\
\hline 151131 & BRRI dhan29× PUB & 7479 & 2579 & 14035 & 544 \\
\hline 136806 & BRRI dhan29×USG & 4900 & 77 & 424 & 551 \\
\hline 136335 & BRRI dhan29×PUA & 4823 & 41 & 294 & 717 \\
\hline 136218 & BRRI dhan28×USG & 4782 & 4782 & 54808 & 1146 \\
\hline 81470 & BRRI dhan29×NO & 0 & & 15314 & \\
\hline 66083 & BRRI dhan $28 \times$ NO & 0 & & & \\
\hline
\end{tabular}


Yield Response and Nitrogen Use Efficiency of Boro Rice Varieties as Affected by Different Methods
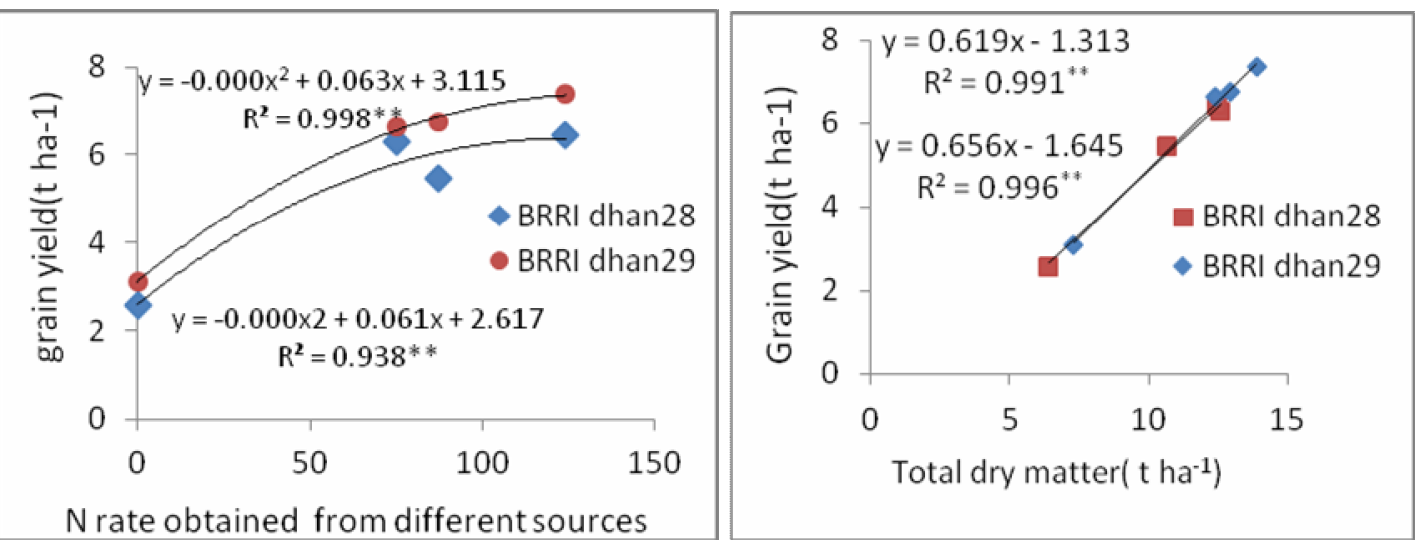

Fig.1. Relationship between grain yield and $\mathrm{N}$ rate obtained from different sources (Fig. $1 \mathrm{~A}$ ) and total dry matter and grain yield of rice varieties BRRI dhan28 and BRRI han29 (Fig. 1B),

** Significant at the 0.05 probability level

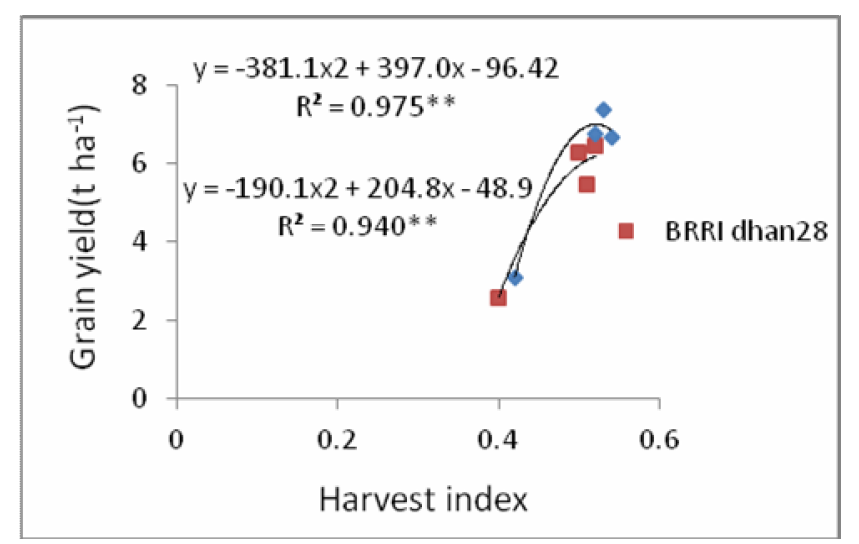

Fig. 2. Relationship between harvest index and grain yield 
Bhuiyan et al.
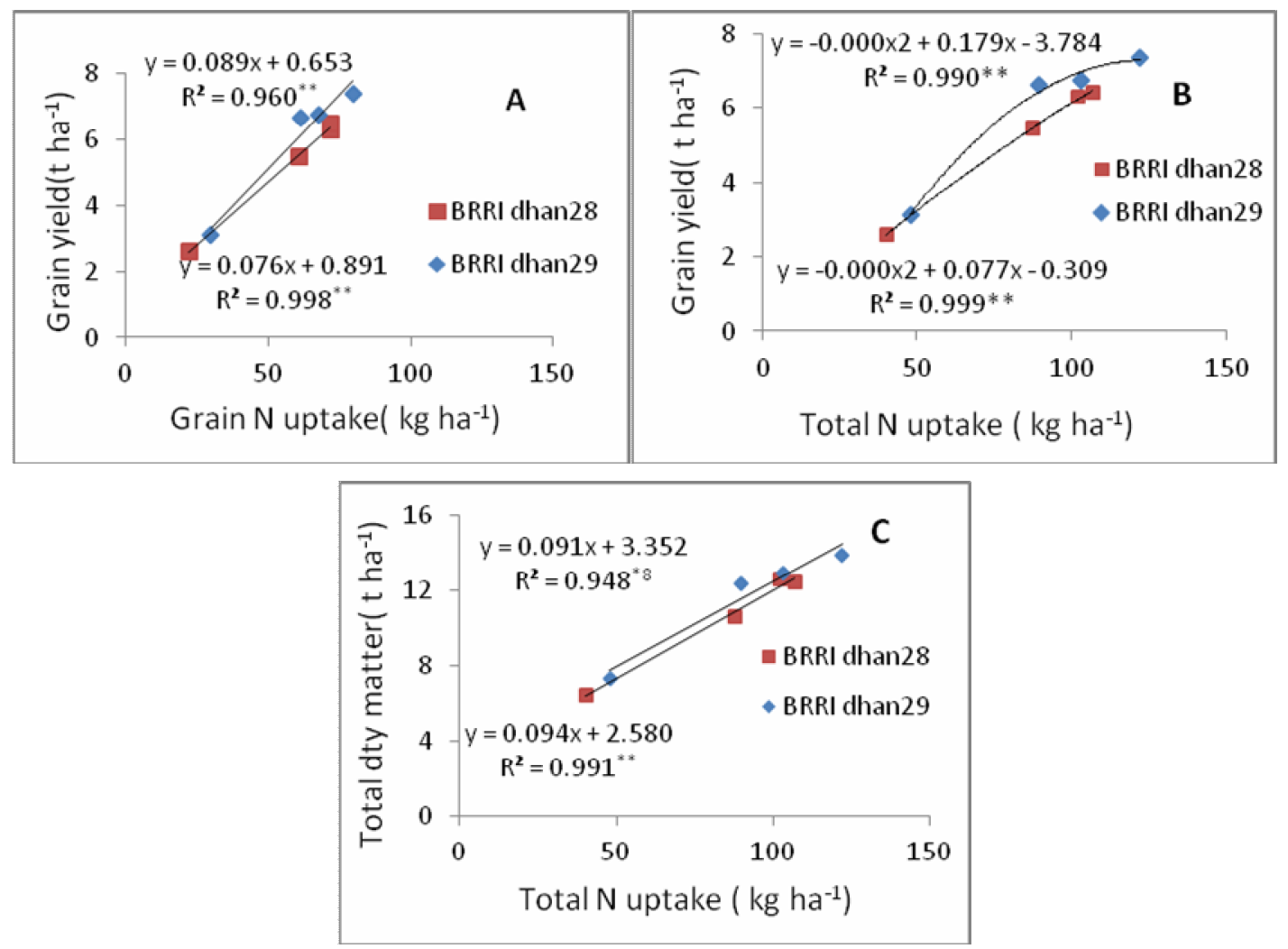

Fig. 3. Relationships between $(A)$ grain $N$ uptake and grain yield, $(B)$ total $N$ uptake and grain yield, and $(C)$ total $N$ uptake and total dry matter production of rice varieties BRRI dhan28 and BRRI dhan29.

** Significant at the 0.05 probability level

\section{References}

Bremner, J. M. and C. S. Mulvaney. 1982. Total nitrogen. In: A. L. Page, R. H. Miller, D. R. Keeny (eds.). Methods of Soil Analysis. American Society of Agronomy and Soil Science Society of America, Madison, USA. Pp. 1119-1123.

CIMMYT. 1988. From agronomic data to farmer recommendations: An economics training manual. Completely revised edition. Centro Internacional de Mejoramiento de Maize y Trigo (CIMMYT), Mexico D.F., Mexico.

Fageria, N. K., V. C. Baligar and C. A. Jones. 1997. Growth and Mineral Nutrition of Field Crops. 2nd Ed.; Marcel Dekker, Inc.: New York.

Fageria, N. K. and V. C. Baligar. 2001. Lowland rice response to nitrogen fertilization. Commun. Soil Sci. Plant 32: 1405-1429. 
Yield Response and Nitrogen Use Efficiency of Boro Rice Varieties as Affected by Different Methods

Fageria, N. K. and M. P. Barbosa Filho. 2001. Nitrogen use efficiency in lowland rice genotypes. Commun. Soil Sci. Plant 32: 2079-2090.

Fatema-Tuz-Zohra, R. Ali, M. Salim and M. A. Kader. 2013. Effect of urea super granules on the performance of transplant aman rice. J. Agrofor. Environ. 7(1): 49-52.

Hoque, M. A., M. Wohab, A. M. Hossain, K. K. Saha and M. S. Hassan. 2013. Improvement and evaluation of BARI USG applicator. Agric. Eng. Int.: CIGR J. 15(2): 87-94.

Kiniry, J. R., G. McCauley, Y. Xie and J. G. Arnold. 2001. Rice parameters describing crop performance of four U. S. cultivars. Agron. J. 93: 1354-1361.

Pamela, A., C. Bonomelli and F. Meza. 2009. Nitrogen application in irrigated rice grown in Mediterranean conditions: Effects on grain yield, dry matter production, nitrogen uptake, and nitrogen use efficiency. J. Plant Nutr. 32: 1574-1593.

Singh, U., J. K. Ladha, E. G. Castillo, G. Punzalan, A. Irol-Padre and M. Duqueza. 1998. Genotypic variation in nitrogen use efficiency in medium and long duration rice. Field Crops Res. 58: 35-53. 